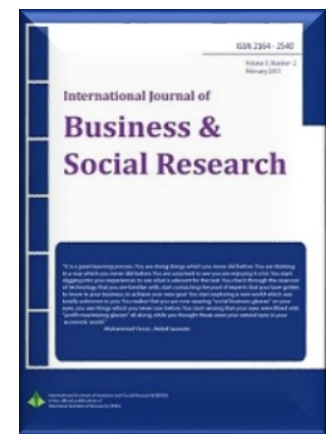

\title{
Vertical Specialization of Production: Critical Review and Empirical Evidence for the Mexican Manufacturing Industries 1994-2014
}

\author{
Maritza Sotomayor ${ }^{2}$
}

\begin{abstract}
This paper surveys Vertical Specialization (VS) from different empirical approaches, including the various conceptualizations of VS, the problems with its quantification, and a case study. The empirical estimation of this paper refers to the Mexican manufacturing industry and the in-bond industry (also known as maquiladora). The purpose of this paper is to compare VS, through the application of the Vertical Intra-Industry Trade (VIIT) indexes, for maquiladora and non-maquiladora industries and to contrast the degree to which the maquiladora industry is integrated with the global value chain relative to the non-maquiladora activities for the 1994-2006 period. Furthermore, this paper quantifies VIIT for the post-maquiladora period (2007-2014) in order to discuss if there have been changes in the VIIT since the conclusion of the maquiladora program in 2006. In particular, this paper tests if the quality ladder hypothesis applies to Mexico for its bilateral trade with the United States and Canada. The empirical estimations show the remarkable differences between maquiladora and nonmaquiladora VS and the impacts that changes in the NAFTA tariff schedule for the automotive industry have had on the bilateral trade pattern.
\end{abstract}

Keywords: Domestic content, intra-industry trade, Mexican trade, NAFTA, vertical specialization.

JEL Codes: F1, F14, F15, O50

Available Online: 18-03-2016

This is an open access article under Creative Commons Attribution 4.0 License, 2016.

\section{$1.0 \quad$ INTRODUCTION}

According to the World Trade Organization (WTO), world exports in parts and components have more than doubled in the 1995-2011 period with an average rate of growth of 4.8\% (WTO-IDE-JETRO, 2011). Feenstra (1998) coined the term trade integration and disintegration of production to describe this new trend in global production and trade where intermediate inputs cross over international borders several

\footnotetext{
${ }^{1}$ The author would like to thank the anonymous reviewers for their useful comments and Rebecca Disrud for her help with the final editing of this document.

2 Finance and Economics Woodbury School of Business Utah Valley University, Orem, UT 84058-5999, Phone: 801-863-6502, Fax: 801-863-7218, E-mail: maritza.sotomayor@uvu.edu
} 
times. Likewise, one of the primary effects of product globalization is the increase of Vertical Specialization (VS), which is explained by technological advances in transportation and communications. The development of information technologies along with decreasing telecommunications and service costs allows effective communication between companies and their subsidiaries, thereby reducing risks involved in a vertical integration production process (Jones \& Kierzkowski, 1990).

While extensive and well-documented theoretical formalizations of the VS exist, measuring the trade of goods in different stages of production has proved complex when using international statistics, where final goods stand out over intermediate goods. The latest revisions of international trade classifications include a greater number of intermediate goods; however, the Input-Output tables might provide a better approximation of this phenomenon since they allow quantification of imports that target export production. ${ }^{3}$ Some researchers have used a combination of international trade statistics and I-O tables to study in more detail the trade of goods in different stages of production (Amador \& Cabral, 2009; Breda et al., 2008; Dean et al., 2011; Lopez \& Homes, 2011; Koopman et al., 2014, 2012).

Furthermore, in some cases, the Intra-Industry Trade (IIT) index has been redefined to include the trade of goods in different stages of production. IIT concerns the flows of final goods within the same industry, which can be horizontal (i.e. same quality differentiated goods) or vertical (i.e. different quality products) representing the trade of final goods. However, several authors (Ando, 2006; Pittiglio, 2014; Türkcan, 2005, 2011) treat vertical trade as trade in different stages of production, quantifying vertical IIT to approximate the flow of intermediate goods.

In this context, the purpose of this paper is to survey VS from different empirical approaches, conceptualizing VS, identifying the problems with its measurement, presenting alternatives to VS, and ending with a case study. The empirical estimation of this paper refers to the Mexican manufacturing industry and the in-bond industry (also known as maquiladora) for the 1994-2014 period. A significant component of Mexican manufacturing trade was the maquiladora trade flows until 2006, after which maquiladora flows became part of the total trade. ${ }^{4}$ The Mexican case is particular since the influence of the automotive industry determined many of the changes in the maquiladoras' degrees of VS throughout the study period. In this respect, comparing vertical specialization for the non-maquiladora and maquiladora industries shows how Mexican manufacturing is integrating into the global value chain production.

Previous research on VS has not differentiated between maquiladora and non-maquiladora trade flows, which can be misleading for the Mexican manufacturing industry's position in the global value chain production. For example, Castillo and de Vries (2013) and De la Cruz et al. (2013) consider the domestic content of exports for the maquiladora industry with no comparison to the non-maquiladora, while Lopez and Holmes (2011) explain the case of the Mexican maquiladora within the NAFTA context. On the other hand, Borga and Zeile (2004), Amador \& Cabral (2009), and Daudin et al. (2011) have studied Mexican trade at the aggregate level with no references to the maquiladora industry. This study attempts to close this gap in the empirical literature.

The purpose of this study is to compare VS - through the use of VIIT indexes - for the maquiladora and non- maquiladora industries to contrast the degree to which both of these industries were integrated into the global value chain for the 1994-2006 period. Furthermore, this paper measures VIIT during the post-maquiladora period (2007-2014) in order to assess changes in VS since the conclusion of the maquiladora program in 2006. In particular, this paper tests the quality ladder hypothesis for the

\footnotetext{
3 The Organization for Economic Cooperation and Development (OECD) has published Input-Output Tables (IOTs) for all OECD members and selected non-OECD members since 1995.

4 The maquiladora industry accounted for about 50 percent of total trade for this country from the eighties until 2006. The North American Free Trade Agreement (NAFTA) accord called for the gradual elimination of the special tariff treatment the maquiladora industry had had and the program ended in 2006. Even though there is still trade of products in different stages of production, INEGI (Mexican statistics office) stopped the registration of this type of trade flows.
} 
Mexican manufacturing trade pattern. In this regard, the present article focuses on the changes produced in the VIIT after the conclusion of the maquiladora program. We confirmed that during the maquiladora years, vertical IIT was a reflection of back and forward transactions, as export prices were higher than import prices, with high portions of imported content in its exports. The non-maquiladora industry showed a similar trade pattern until 2003 when the NAFTA tariff schedule for the automotive industry shifted and the trade pattern took on a more horizontal nature. After 2006, when maquiladora trade flows became part of the total trade, we found that VIIT did not increase significantly. Still, with these changes in the trade pattern, our quantitative estimations show that VS occurred in the Mexican manufacturing industry with a significant component of back-and-forth transactions. The evidence is even clear when examining bilateral trade with the U.S. and with Canada.

The remainder of this paper is organized as follows. The second section surveys the problems with defining the term VS. In the theoretical and empirical literature VS takes several names, and this section will demonstrate how this concept has changed over time. The third section reviews literature of theoretical approaches to the challenges in measuring VS, the main issues resting on the selection of databases, and the problems with international trade statistics. The fourth section examines the case of the Mexican manufacturing industry, testing the quality ladder hypothesis using Ando's (2006) methodology for both the maquiladora and no-maquiladora industries. This paper concludes with final remarks on the main findings.

\subsection{DEFINING VERTICAL SPECIALIZATION}

A first step in the analysis of VS is to define VS. In the empirical and theoretical literature, VS has been used as a synonym with international fragmentation, product sharing, and vertical IIT, all terms which are usually only differentiated in a footnote. ${ }^{5}$ This paper contributes to the literature first by consolidating the names for the internationalization of production across different countries. This article does not aim to determine the best term, but rather to track the evolution of the term according to different theories and empirical perspectives. The most frequently mentioned terms are listed below in Table 1.

Table 1: Different terms for vertical specialization

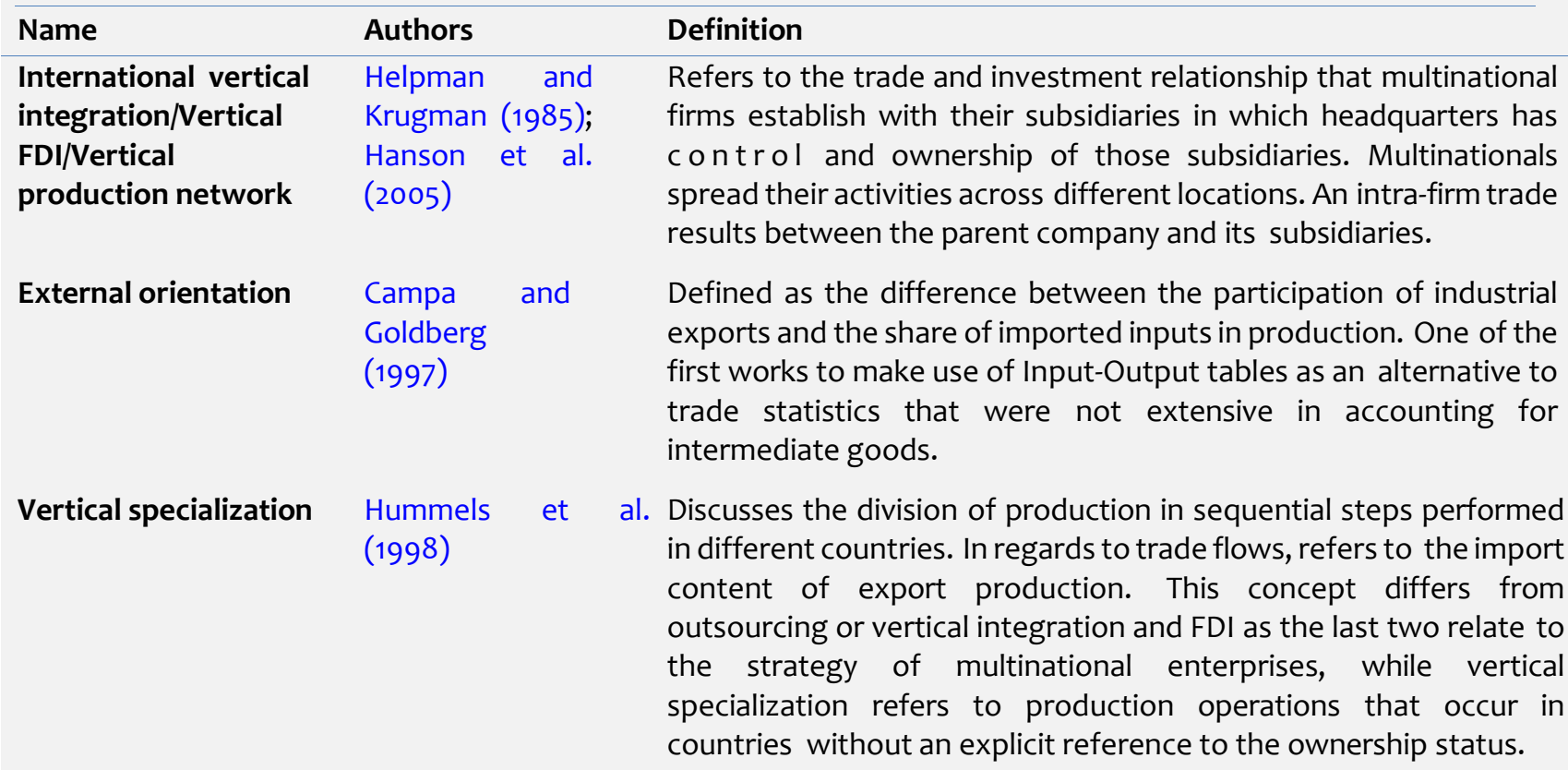

5 For example Nordas, (2008); OECD, (2009) and Amador and Cabral (2009) used VS as synonymous with fragmentation, production-sharing, offshoring, and international production networks. 


\begin{tabular}{|c|c|c|}
\hline $\begin{array}{l}\text { Subcontracting/ } \\
\text { Outsourcing/ } \\
\text { Offshoring }\end{array}$ & $\begin{array}{l}\text { Feenstra } \\
\text { (1998); } \\
\text { Feenstra and } \\
\text { Hanson 1996a, } \\
\text { 1996b, 1997, } \\
\text { 2003) }\end{array}$ & $\begin{array}{l}\text { Defined as the practice in which a company divides production } \\
\text { stages and then locates each stage in a country where the costs are } \\
\text { the lowest. It includes the practice of hiring a third party } \\
\text { (subcontracting) that conducts the whole production process, } \\
\text { keeping the company logo (e.g., NIKE.). }\end{array}$ \\
\hline $\begin{array}{l}\text { Intra-product } \\
\text { specialization }\end{array}$ & Arndt (2001) & $\begin{array}{l}\text { Refers to the trade in parts and components that corresponds to } \\
\text { the same end use of a good. Depending on the product, imports of } \\
\text { parts and components are not only for assembly, but also for } \\
\text { transformation into other parts and components which in turn are } \\
\text { exported either for final assembly in the country of origin or in a } \\
\text { third country. }\end{array}$ \\
\hline $\begin{array}{l}\text { International product } \\
\text { sharing }\end{array}$ & Yeats (2001) & $\begin{array}{l}\text { Defined as the internationalization of manufacturing in which } \\
\text { countries participate in different stages of the manufacturing of } \\
\text { goods. Stages of production are located in the most efficient and } \\
\text { lowest cost site. Additionally, it refers to special tariff provision } \\
9802 \text { (previously } 806 / 807 \text { ) of the Offshore Assembly Program } \\
\text { (OAP) that governs trade in parts and components, not only } \\
\text { between the U.S. and Mexico but also between other partner } \\
\text { countries. }\end{array}$ \\
\hline $\begin{array}{l}\text { International } \\
\text { fragmentation of } \\
\text { production }\end{array}$ & $\begin{array}{l}\text { Baldone et al. } \\
\text { (2001); Jones and } \\
\text { Kierzkowski (1990, } \\
\text { 2001) }\end{array}$ & $\begin{array}{l}\text { Defined as the segmentation of the product chain that is carried } \\
\text { out in different countries, either by multinational enterprises or } \\
\text { companies that hire third-party services. Made possible by } \\
\text { technological innovations in communications and transport and } \\
\text { the liberalization of financial services. }\end{array}$ \\
\hline Trade in tasks & $\begin{array}{l}\text { Grossman and } \\
\text { Rossi- } \\
\text { Hansberg } \\
(2006)\end{array}$ & $\begin{array}{l}\text { Assumes that the production of goods requires ongoing tasks for } \\
\text { each of the factors of production. Once determined, tasks can } \\
\text { determine what can be done in different locations assuming that } \\
\text { marginal costs at all locations are equal. }\end{array}$ \\
\hline Value-added trade & $\begin{array}{l}\text { Daudin et al. (2011); } \\
\text { Koopman } \\
(2012)\end{array}$ & $\begin{array}{l}\text { The growth of intermediate goods implied a redefinition of what is } \\
\text { registered as a final good since a product in different stages of } \\
\text { production crosses several borders until it becomes a final good. } \\
\text { Therefore, the value-added of a good needs to be considered } \\
\text { instead of the final value of a good. }\end{array}$ \\
\hline
\end{tabular}

As Table 1 shows, several components of the definition are common to the different terms. Firms slice up production and divide it among different locations abroad (offshoring), with (intra-firm) or without (third-party service) ownership links. Parts and components or intermediate goods can cross borders several times, transformed as final products or as more elaborated intermediate goods. These products can go back to the same country or end up in a third or fourth country. ${ }^{6}$ Another common element is the domestic content of exports or the quantity of imports embedded in exports, since the final market is the global market. Lastly, multinational firms have contributed to the expansion of this new international economic specialization.

Questions about the correct term for a production process spread among different countries often arise, but terminology depends on the focus of the study. VS has been used as synonymous with product-sharing, intra-product specialization, external orientation, fragmentation and trade-in-tasks, for example.

Several authors have made adjustments to definitions of Hummels et al. (1998) or Hummels et al. (2001) to match their theoretical approaches (Daudin et al. 2011; Dean et al., 2011; Jiang \& Milberg, 2012; Koopman et al., 2012; Meng et al., 2010; Nordas, 2008; OECD, 2009; Ricotta, 2009; Yang et al., 2015). Other

\footnotetext{
${ }^{6}$ Kierzkowski (2011) shows a diagram of flows for different types of trade.
} 
authors have offered working definitions. For example, Krugman (2008) sees VS as the breakup of the value chain that allows developing countries to take over unskilled labor-intensive portions of skilled laborintensive industries. Lopez and Holmes (2011) consider VS as the splitting up of production structures across national boundaries to gain cost advantages in production sequences.

In this study, Vertical Specialization refers to a production structure that involves moving stages of production (which generate a flow of trade in parts and components) across national borders, independent of an ownership link between the parties. Thus, a firm can decide which locations and which factors of production are more efficient under lower production costs. This definition includes both the multinational enterprise disintegrated production at a global level and firms that offshore services to third parties. Since the focus of this study is the Mexican maquiladora and non-maquiladora industry, the paper will use a similar definition to Hummels et al. (2001) and Jones and Kierzkowski (1990, 2001). The next section will cover theoretical and empirical issues regarding Vertical Specialization.

\subsection{LITERATURE REVIEW}

\subsection{THEORETICAL APPROACHES}

Campa and Goldberg (1997) created a theoretical framework that would explain the causes and economic implications of fragmentation on the structure and composition of trade. The new trade theory explains trade in final goods in a context of imperfect competition and product differentiation. Nevertheless, it does not provide appropriate background for the analysis of intermediate goods whose trade can be better explained in a context of comparative advantages and differences in factor endowments.

The localization of fragments of intermediate goods production in different regions or countries takes advantage of differences in productivity and factor prices as suggested in the Ricardian theory of comparative advantages. In this respect, the analysis of VS and fragmentation means a return to the Ricardian comparative advantage theory and the Heckscher-Ohlin-Vanek (HOV) model; together, the two models create a framework to explain the operation of production segmentation.

The theoretical model developed by Jones and Kierzkowski $(1990,2001)$ has verified the feasibility of fragmented processes in the new area of international trade and can be explained within the classical theories of Ricardo and HOV. Jones and Kierzkowski's $(1990,2001)$ contribution is to point to the advances in communications engineering and financial services as the main drivers of international fragmentation of production. Technological development of services (transportation, communications, and financial services) has enabled integrated production processes that can be broken into two or more production segments and coordinated through service links (Jones and Kierzkowski 1990). ${ }^{7}$ Based on differences in factor endowments, the authors determined the pattern of product specialization between countries in which fragmentation should be seen as the result of biased technical progress.

Feenstra and Hanson have studied patterns of trade specialization with special focus on the North-South trade in several works. In several joint (1996, 1997, and 2003) and separate papers (Feenstra, 1998; Hanson, 1996; Hanson et al., 2005), they analyze offshoring and its effects on the labor market (specifically on the demand for skilled labor and wages in the country of origin and the host country). Feenstra and Hanson point out differences in factor endowments and factor intensities as premises for deciding the fragmentation of production. According to them, offshoring can take the form of imported intermediate inputs (parts and components) as well as of service for the assembly of a product

\footnotetext{
7 In a later work, both authors (Jones \& Kierzkowski, 2005) extend their analysis to include the significance of service links as the source of increasing returns in the production process when stages of production can be moved out to several nations.
} 
overseas while keeping the brand or company logo. ${ }^{8}$ They state that outsourcing will contribute to the growth of demand for skilled labor in both states, and consequently to increasing wages (Feenstra \& Hanson, 2003). Thus, outsourcing increases the wage gap between skilled and unskilled labor, which can be considered as a form of technological change in capital intensive activities (as was also stated by Arndt, 2001; Deardorff, 2001; Jones and Kierzkowski 1990, 2001). In the same vein, Shelburne (2004) stresses that outsourcing results in a biased technological change with an increase in inequality in both developed and developing countries through downward pressures on wages for unskilled labor.

Kleinert (2003) recognized that trade patterns of intermediate goods differ from trade in final goods and extended Feenstra and Hanson's models accordingly in order to study the factors behind the increasing share of intermediate goods in total imports by developed countries, in particular when Foreign Direct Investment (FDI) is the reason for this type of trade. Kleinert builds a model that includes intermediate goods in the production function of Multinational Enterprises (MNEs). The model highlights the relationship between foreign affiliates and the home-country supplier network and predicts that the MNEs' subsidiaries abroad tend to import intermediate goods in a greater proportion than the national counterpart (Kleinert 2003).

Another stream of research examines trade flows of intermediate goods that relate to the flow of intraindustry trade (IIT), which can be considered part of the new trade theory. Ethier (1982) was one of the first to extend a theoretical model of horizontal IIT in differentiated intermediate goods based on Dixit and Stiglitz's (1977) preferences for variety. However, a later work by Lüthje (2003) cautions that Dixit and Stiglitz's ideas on preferences for variety cannot be used to analyze trade in intermediate goods since variety is not important for the intermediate goods demand because the intermediate goods need to meet the final good product specifications. Lancaster's preferences for an ideal better explain this type of trade (Lüthje 2003). Differences in factor endowments between countries again determine the pattern of trade specialization. Indeed, analyses of trade in intermediate goods often assume that the number of available varieties of intermediate goods in the production of a final good is negatively related to the difference in factor endowments between countries, while the number of adaptations in the intermediate good production of a final good is positively related to differences in factor endowments between countries.

A more recent explanation for the relationship between VS and intermediate goods comes from the theoretical framework where VS can be denoted as trade-in-task. The pioneering work of Grossman and Rossi-Hansberg (2006) indicates that the increase in the trade of parts and components, more than the trade in final goods in the last two decades, reflects changes in firms' production strategies. Instead of a production process that maximizes the best combination of inputs at lowest costs, firms seek production processes where tasks are performed at the lowest costs. On this subject, Grossman and Rossi-Hansberg offer a new paradigm with seemingly contradictory implications for standard trade theory (Baldwin \& Nicoud, 2014). Outsourcing of tasks affects the price of inputs and their productivity as well as trade policy. As noted by previous works, technological change is occurring at home and in host countries. In this case, Grossman and Rossi-Hansberg's theoretical model shows that offshoring tasks will increase productivity of factors involved in those tasks and thus increase wages.

Hitherto, researchers have seen VS in relation to trade of intermediate goods, explained by differences in factor endowments between countries and facilitated by the decrease of transportation and communication costs. Furthermore, the traditional North-South inter-industry trade specialization changed with the rise of vertical IIT led by the flows of intermediate goods. One of the primary challenges in the analysis of VS has been the issues with measurement. The next section will review the empirical evidence related to the quantification of VS and the databases used in order to quantify the trade of intermediate goods.

\footnotetext{
${ }^{8}$ The authors remark that vertical specialization is not only limited to the activities of multinational enterprises, but extends to the case of third-party firms that provide customer-supplier relationships for producing at different production segments.
} 


\subsection{EMPIRICAL EVIDENCE AND MEASUREMENT ISSUES}

The quantification of vertical specialization has shared the same problems of measurement that once affected scholars studying IIT. A common concern has been problems in the registration of international trade statistics. An analysis of trade flows of goods in different stages of production requires at least one record of trade in intermediate goods (Grunwald \& Flamm, 1985; OECD, 2009) and trade nomenclatures were not designed to identify products by their end use (Lopez and Holmes 2011). The first version of the international trade statistics, Standard International Trade Classification (SITC), included a small number of intermediate goods. Subsequent revisions of SITC (Revisions 2 and 3) considered a greater number of parts and components; however, the identification of assembled products and components is not yet resolved. Yeats (2001) also emphasizes that the databases of international trade are not sufficient to determine the actual location of production of parts and components, direction and composition of trade, or magnitude of this business. In a first attempt to quantify this trade, Yeats used trade data from the OECD (SITC Rev. 2 and 3) and from the Offshore Assembly Program (OAP) ${ }^{9}$ to examine the trade in parts of the industrial category 7: Machinery and Transportation, for a selected group of OECD countries. For the 1978-1995 period, trade in parts and components has grown faster in countries that maintained regional trade agreements. Developing countries were the main destinations of exports of intermediate goods, with China as the country with the fastest growth during this period.

Since fragmentation refers to the production and trade of goods at different stages of the production chain, the Input-Output (I-O) tables have been another source of data used to quantify this trade. Campa and Goldberg (1997), Hummels et al. (1998) and Hummels et al. (2001) quantitatively approached the phenomenon of fragmentation using I-O tables (Amador \& Cabral, 2009; Breda et al., 2008; Dean et al., 2011; Koopman et al., 2014, 2012, Daudin et al. 2011; Jiang \& Milberg, 2012; Koopman et al., 2014, 2012; Meng et al., 2010; Nordas, 2008; OECD, 2009; Ricotta, 2009; Yang et al., 2015). All three works have drawn attention to the growing share of intermediate goods in world trade and the need for quantification in order to assess potential impacts on the rest of the economy.

Campa and Goldberg (1997) used I-O tables to quantify the external orientation of manufacturing industries by measuring four indexes (export share, import share, imported inputs share, and industry export share) to assess the effects external shocks have on selected manufacturing sectors for some developed countries. The indexes reveal the high content of imported intermediate goods in manufacturing exports. Hummels et al. (1998) also proposed I-O tables to estimate VS by quantifying the value of imports contained in export products. The authors quantified VS for ten OECD developed countries, estimating that tariff and non-tariff reductions have served to promote VS. Similarly, with economic and financial liberalization, FDI becomes a complement to trade for these countries. For instance, Hummels et al. (2001) extend the sample to include developing countries such as Mexico.

I-O tables have several advantages for the calculation of VS since they include the number of imported inputs, gross output, value-added and exports. Likewise, the I-O tables record inputs imported from another sector making it possible to estimate the value of imported inputs that are indirectly employed in the production of exports. Despite these advantages, the tables present a problem of aggregation, since the measurement of imported inputs and exports is done at the level of the industry and not the product (Hummels et al. 1998).

Following Hummels et al. (1998) and Hummels et al. (2001) and the use of I-O tables, the quantification of VS and fragmentation has been prolific. Some works refer to the analysis of individual countries (Bastos \& Silva, 2010; Koopman et al., 2014, 2012; Nordas, 2008; Ricotta, 2009; Yang et al., 2015 Dean et

\footnotetext{
9 The OAP was established in 1964 by the U.S. government to facilitate the production and assembly of parts and components outside national borders. Commercial rates $806 / 807$ (grouped since NAFTA under 9802.00 .60 and 9802.00 .80 rates respectively) exempt from tariffs on imports those goods previously exported for further processing or assembly abroad. Similarly, the European Union has a similar program, the Outward Processing Trade (OPT) to exempt from tariffs intermediate goods processed outside the EU, where members took advantage of lower labor costs in countries of Eastern Europe and particularly in those labor-intensive industries like textiles, auto parts, and electronics.
} 
al., 2011), regions (Breda et al., 2008; Inomata, 2008), or to a select number of countries (Amador \& Cabral, 2009; Koopman et al., 2012, Daudin et al. 2011; Jiang \& Milberg, 2012; Meng et al., 2010; OECD, 2009; Ricotta, 2009; Yang et al., 2015). Other studies concentrate on the determinants of VS (Clark, 2010b; Lopez and Holmes 2011; Nordas, 2008) or on the supply-driven I-O model (Gosh's I-O framework) to measure the degree of VS (Meng et al., 2010). Some of these analyses recognize the I-O tables' limitations and combine different sources of information to contrast their results. Such is the case of Nordas, (2008) and Daudin et al. (2011) with the use of the Global Trade Analysis Project (GTAP) database, or of Amador \& Cabral (2009) who combine information coming from I-O tables with trade statistics from the CEPII - CHELEM database. Studies such as Koopman et al., (2014, 2012) offer a more detailed measurement of intermediate goods, differentiating between those related to processed imports and regular imports (non-split and split I-O tables).

The quantitative empirical evidence of the measurement of VS in relation to fragmentation is not as vast but more diverse. In that vein are several analyses that come from the Product Sharing framework. Clark et al. (1993) used the database of the OAP program to examine the likelihood that a company would decide to outsource. The results show that the probability of sub-contracting is negatively related to the capital/labor ratio, transport costs and non-tariff rates, while positively related to tariff rates and import penetration. Their findings support the view that outsourcing has become a substitute for domestic production to meet competition in the local market. Feenstra (1998) uses the United States International Trade Commission (USITC) and the Bureau of Economic Analysis (BEA) databases to analyze the composition of U.S. trade for selected years between the 1925-1995 period. The products are classified according to use. The data analysis does not focus on the amount of trade due to the fragmentation of production; it is obtained instead from what is taken for trade in goods in different stages of production. Feenstra confirms with this work a trend towards disintegration of production in an increasingly integrated world economy. BEA data have also been useful in examining the behavior of FDI by multinational firms.

Following the theoretical framework of Ando (2006) studies the case of East Asian countries by estimating vertical IIT flows. Fragmentation can be measured as the significance of vertical IIT in the total trade flows between North-South countries. Products in different stages of production show unit price differentials, not only reflecting differences in quality, but also in back-and-forth transactions. According to Ando, "if most vertical IIT in lower-income countries is systematically of commodities with export prices lower than import prices and most vertical IIT in higher-income countries is of commodities with export prices higher than import prices, then the assumption of a quality ladder hypothesis may hold. If that is not the case, on the other hand, then vertical IIT may include not only trade of quality differentiated commodities, but also back-and-forth transactions with value-added embodied in vertically fragmented production processes in the same commodity category" (p.271). This empirical approach is particularly significant for countries that have tried to transform their trade pattern from low quality intermediate products (back-and-forth transactions) to high quality differentiated goods. This paper will follow Ando's (2006) methodology to study the case of the Mexican manufacturing industry disaggregating between maquiladora and non-maquiladora for the 1994-2014 period.

So far this review has highlighted the main issues with the quantification of trade flows of goods in different stages of production, pointing out the difficulties with international trade databases as well as the need to combine different sources of information to contrast results. In the next section, we will examine the case of the Mexican maquiladora and non-maquiladora industry. This paper offers an alternative means to estimate Mexican manufacturing trade flows according to Ando's approach to test the quality ladder hypothesis and verifies if the Mexican manufacturing industry has remained at the back-and-forth transactions level or if it has grown to the high quality differentiated vertical IIT flows level. 
The literature review of VS provides the framework for applying the IIT indexes according to Ando's (2006) methodology to the Mexican manufacturing industry, differentiating between the maquiladora and non-maquiladora industry. We aim to offer an alternative quantification for trade in goods at different stages of production or intermediate goods and to provide a more disaggregated analysis that considers the significance of the maquiladora industry in the Mexican trade sector.

More accurately quantifying maquiladora trade flows requires using I-O tables to verify the degree of VS that occurs in this sector. As mentioned, previous calculations of the total trade in multilateral studies have included Mexico (Clark, 2010b; OECD, 2009), with a few studies focused only on the maquiladora sector (Castillo and de Vries 2013, De la Cruz et al. 2013, Lopez and Holmes 2011). The contribution of this paper will be the calculation of both (non-maquiladora and maquiladora industry), by estimating the vertical IIT using the Ando (2006) methodology to verify the quality ladder hypothesis. On one hand, the maquiladora industry ended in 2006 and all operations under that program are now part of total trade. On the other hand, one of the issues with the maquiladora industry has been the low integration of domestic value added, which can be seen as back-and-forth transactions. This paper calculates the changes after 2006 and tests if there has been an increase in the quality of differentiated goods after the elimination of the maquiladora program or if the proportion of back-and-forth transactions is significant. The latter means that the comparative advantage of Mexican manufacturing industries continues to be low wages, with all its economic implications. This paper also analyzes the vertical IIT by industrial sectors at a higher disaggregation ( 6 digits), while previous estimations calculated the indexes only from the trade classification (i.e. Valderrama \& Neme, 2011) without correspondence to industrial classification. The distinction is significant since international trade classifications take into account the characteristics of a product, while industrial classifications consider the characteristics of the industrial process, which is relevant when analyzing vertical specialization.

The IIT index is measured following Greenaway and Milner (1984), based on the Grubel and Lloyd IIT index ${ }^{10}$ and is differentiated by its nature in horizontal and vertical IIT carried out according to Fontagné and Freudenberg's (1997) methodology. Therefore, we have these two expressions:

$$
I I T_{j i}=1-\frac{\sum_{j}^{n}\left|X_{j i}-M_{j i}\right|}{\sum_{j}^{n}\left(X_{j i}+M_{j i}\right)} * 100
$$

For $j$ goods ranging from $j=1 \ldots n$ aggregated at $i$ industries sectors. The IIT index can take values ranging from zero to 100. One way trade can be interpreted is as the remainder of expression (1). IIT flows will be horizontal in nature when the ratio of the unit values is in the following range:

$$
\frac{1}{1+\alpha} \leq \frac{U V_{j}^{x}}{U V_{j}^{m}} \leq 1+\alpha
$$

Expression (2) shows $U V_{j}^{x}$ and $U V_{j}^{m}$ as the ratio for the unit values of exports and imports for the good $j$ while $\alpha$ is a threshold value of 25 percent. For a given level of aggregation, IIT is defined as horizontal when exports and imports of simultaneous goods whose unit value of exports compared to imports is within a range $\alpha$, otherwise it will be counted as vertical IIT (Fontagné and Freudenberg, 1997).

As Ando (2006) stated, vertical IIT not only shows the simultaneous trade of products of different qualities; it can also be understood as the flow of goods in different stages of production, VS. Thus, when calculating VIIT an additional step would be to classify VIIT products according to their prices. Higher-income countries would present prices of exports higher than prices of imports, while low or medium-income countries would present the opposite. According to Ando (2006), this fact would

\footnotetext{
10 The Grubel and Lloyd (G-L) index has been most used to check the IIT share in the total traded. However, the index had issues arising from statistical aggregation when calculating at the industrial level. Greenaway and Milner (1984) resolved the problem by calculating a weighted average G-L index. In this paper, the level of industrial aggregation is six digits which further reduces any potential problems with statistical aggregation.
} 
reflect the quality ladder assumption, thus VIIT would be the reflection of a trade of products of different qualities. However, if this were not the case, then VIIT would not only show a different quality products transaction but also back-and-forth transactions of fragmented production processes (Ando 2006, p. 271).

The trade data for the 1994-2006 period is from the Institute of National Statistics, Geography and Informatics (INEGI, its acronym in Spanish) and from COMTRADE for the 2007-2014 period. Since 2007, INEGI has not published trade data differentiated by maquiladora and non-maquiladora as the NAFTA tariff deregulation process called for the elimination of the maquiladora program tariff benefits (Carbajal \& Del Moral, 2014). The maquiladora program switched to a new program called the Manufacturing, Maquila and Export Services Industry (IMMEX, its Spanish acronym) which includes the manufacturing export industry. ${ }^{11}$ For this reason, at trade level data there is no longer a distinction between these two types of trade even though maquiladora activities still exist.

INEGI and COMTRADE have their trade statistics under the Harmonized System (HS) 1996 version; however, the format of the HS has changed over the years. In order to make the different years comparable, we followed the HS 96 version. As for the industrial classification, trade data has been aligned with industrial categories following the Clasificación Mexicana de Actividades y Productos (CMAP) 1994 version for the entire period. Even though the current industrial classification is the North American Industrial Classification System (NAICS) 2012 version, we tried to avoid losing observations when changing from different industrial classifications (NAICS has three versions: 2002, 2007, and 2012). This paper estimates IIT indexes, taking into account the industry definition, while previous empirical research estimated the indexes directly from the trade data without considering the classification of a product according to its end use.

Graph 1 shows the results for the total Mexican IIT compared with the rest of the world, the VIIT and the VIIT where the prices of exports are greater than the prices of imports, all data in percentages, for the 1994-2014 period. The indexes for the non-maquiladora industry are estimated for the 1994-2006 period in Graph 1; after 2006, the indexes include maquiladora trade. Graph 2 presents the same data for the maquiladora industry for the 1994-2006 period.

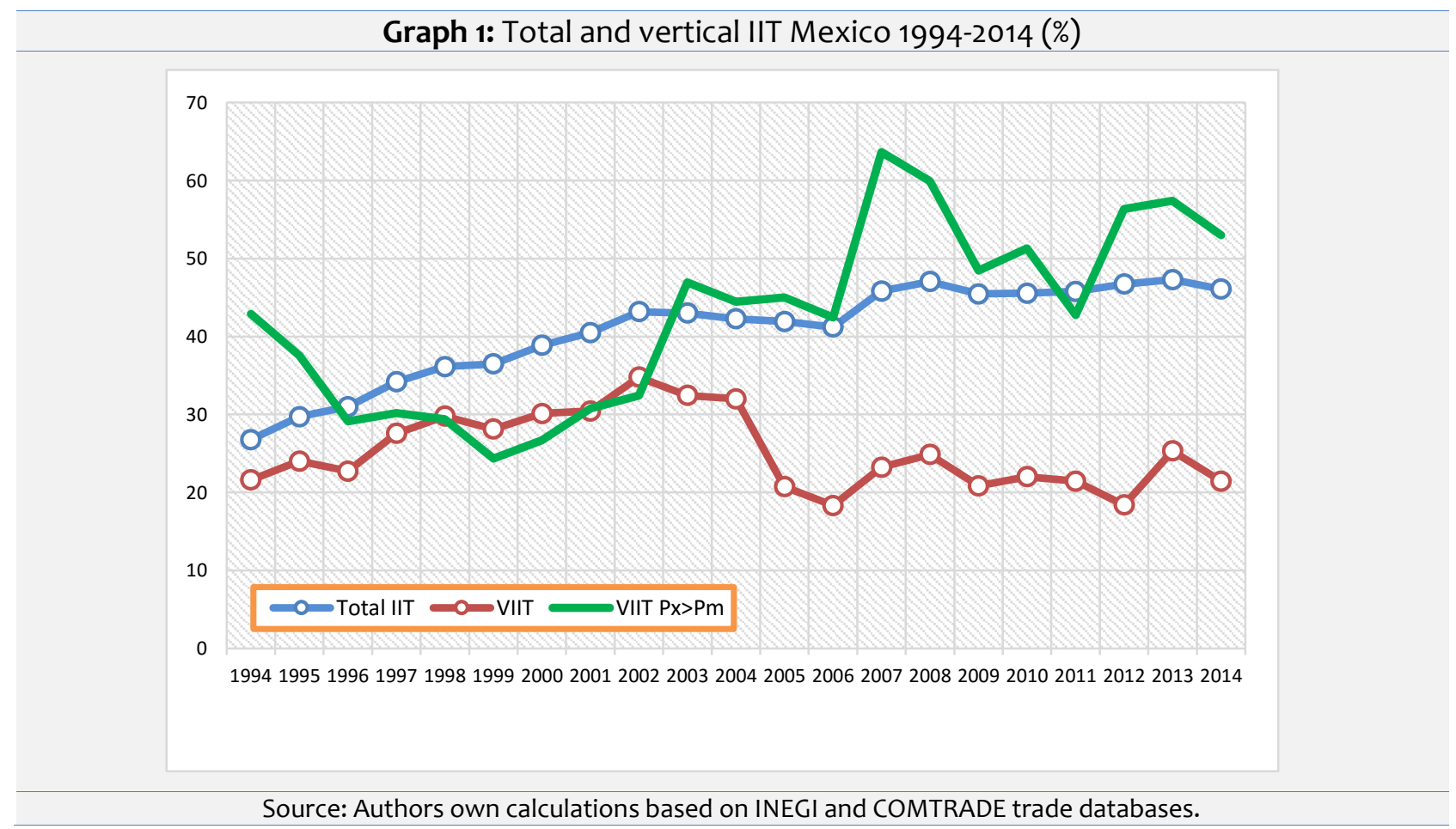

\footnotetext{
11 This program, created November 1 2006, allowed the temporary imports of products directed to the production of manufacturing exports without covering the payment of the general tax for import or the value added tax.
} 


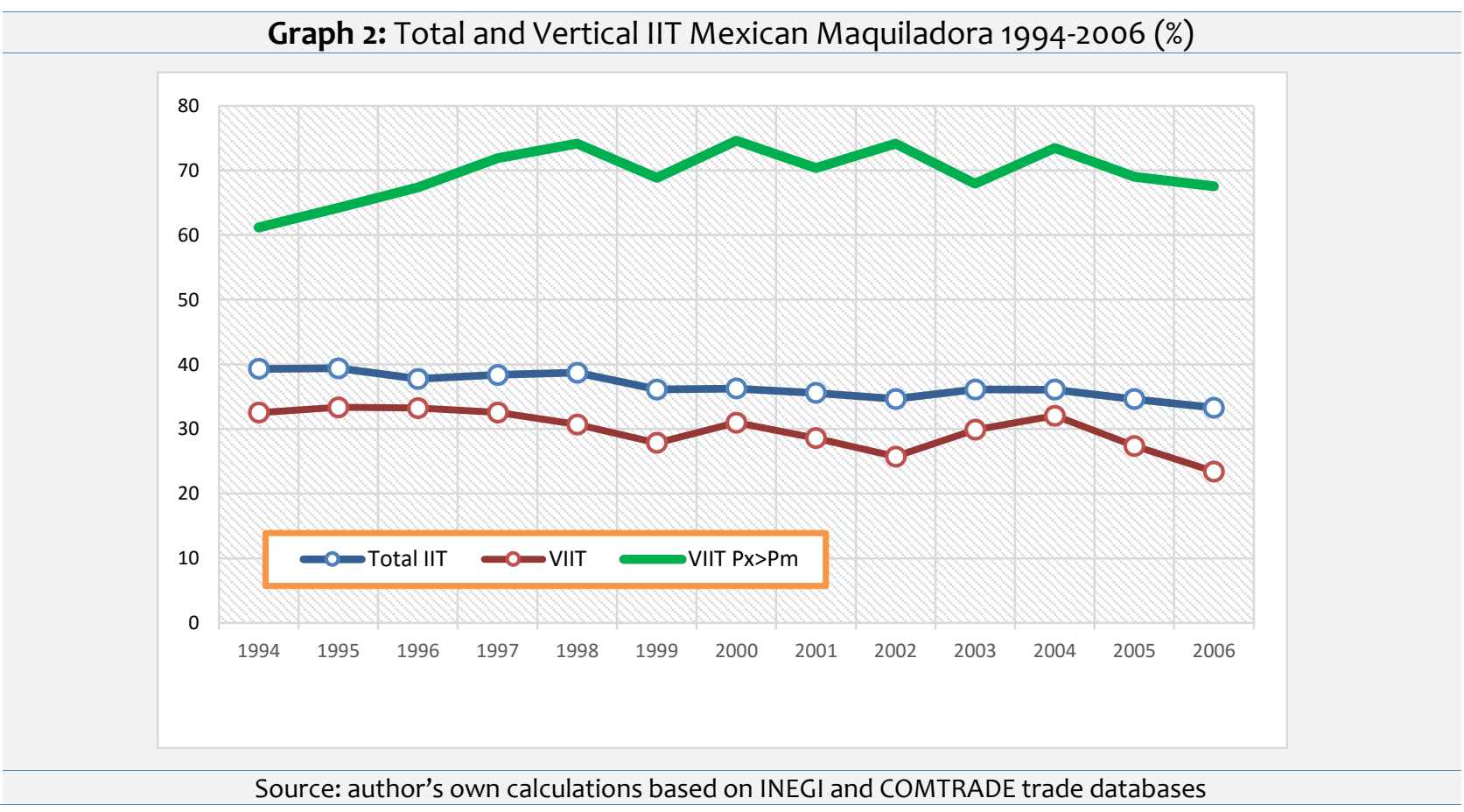

As Graph 1 and 2 show, disaggregating the estimation of IIT results in some differences between maquiladora and non-maquiladora for the 1994-2014 period. The non-maquiladora (Graph 1) reflects significant one way trade, which is more than 50 percent for this period, or in other words, the IIT indexes are less than 50 percent for the studied period. The estimated IIT index in this work is much lower than previous empirical evidence (i.e. Valderrama \& Neme, 2011) since we calculated the adjusted IIT index by taking the maquiladora trade off the total, better reflecting the simultaneous trade of goods that belongs to the same industrial category. ${ }^{12}$ Even though the IIT is moderately low, the Mexican nonmaquiladora IIT has been vertical for the 1994-2006 period, as Graph 1 shows. For example, in 2002 the IIT index was 39 percent, while the vertical IIT was 35 percent, which means that the vertical IIT represented 90 percent of the total IIT. After 2006, changes in the automotive industry (a significant component of total manufacturing trade) influenced higher participation of horizontal IIT. The inclusion of maquiladora operations in the total trade has influenced the aggregate results when compared with the previous period, which suggests that VS in the Mexican manufacturing industry has grown as the result of trade of fragmented product processes.

Graphs 1 and 2 also show the price of exports higher than the price of imports for the vertical IIT products, demonstrating the existence of VS in the Mexican trade. The quality ladder hypothesis predicts that developed countries will present a higher proportion of their vertical IIT where prices of exports are higher than imports, while developing countries will present the opposite. If that relation does not hold in developing countries, then the trade of vertically differentiated products is not only trade of different qualities, but the trade of back-and-forth activities, vertical specialization. Graph 1 shows that for the entire period prices of exports have been higher than prices of imports, in particular since 2006, which coincides with the inclusion of the maquiladora trade flows as part of the total trade. Since VS is more intense after 2006 even though VIIT as a proportion of total trade is lower, the trade pattern is becoming more vertically specialized with back-and-forth trade activities even while horizontal IIT has increased. This could be the result of the trade statistics; however, a trade analysis of bilateral IIT flows between Mexico and the U.S. and Canada will give us a better picture.

Graph 2 shows the results for the maquiladora industry, which present similar trade patterns where IIT is less than 50 percent of the 1994-2006 period. The percentages of IIT and vertical IIT are higher when compared with the non-maquiladora industry, which is understandable since the maquiladora trade is

\footnotetext{
12 Furthermore, this work estimates the IIT indexes by industrial categories, while previous empirical studies estimated the
} indexes using the trade data directly without the correspondence to industry categories. 
in fact the trade of products at different stages of production. The VS nature of the maquiladora industry is shown via prices of exports higher than import prices; more than 60 percent of the vertical IIT contains back-and-forth operations for the period. When differentiated between maquiladora and non-maquiladora, these estimated indexes corroborate the maquiladora industry's VS and the relationship between export and import prices, which reveals the back and forth transactions. This maquiladora trade performance corroborates the results found by Ando (2006) for East Asian countries where the in-bond industry trade (maquiladora) has been the motor of their trade development.

A better calculation of the degree of VS can be performed by an analysis of bilateral trade. Graphs 3 and 4 show the estimation of vertical IIT indexes for the non-maquiladora and maquiladora for the trade between Mexico and the U.S. The graphs include the prices of exports and imports to confirm the VS nature of this trade. The U.S. is the main destination for Mexican exports (around 80 percent), but while the U.S. has been the main origin of imports, since 2001 China has been increasing its trade flows with Mexico in one way (mainly imports). NAFTA has impacted the trade pattern since its implementation in 1994, which we will see in the following graphs.

\section{Graph 3: Total and Vertical IIT Mexico-U.S. 1994-2014}

$(\%)$

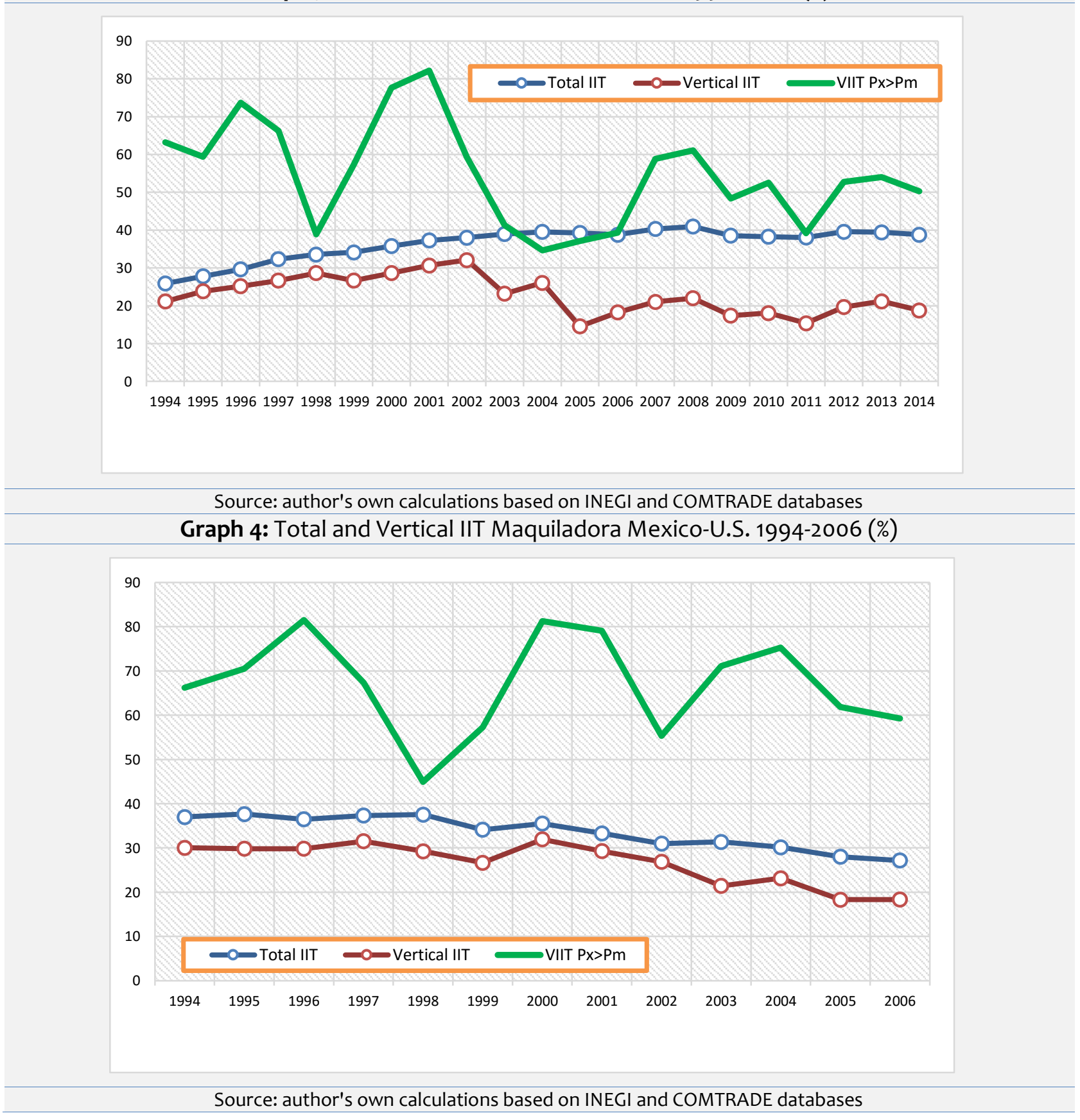


Graph 3 shows the total and vertical IIT in Mexico-U.S. trade for the 1994-2014 period. The data from 1994-2006 shows the non-maquiladora indexes. The indexes share the same trade pattern shown in the first two graphs as the U.S is the main trade partner for Mexico. The total IIT index for non-maquiladoras barely reaches 40 percent. Again, these results are more cautious than previous empirical estimations (Clark, 2010a; Ekanayake et al., 2009). During this period, the non-maquiladora IIT is mainly of a vertical nature until 2003 when significant changes occurred in the trade pattern.

A closer look at the indexes by industrial sectors reveals that changes in the automotive industry are the reason for this change. The industrial sector 3841 automotive industry represents 30-32 percent of the total trade for the non-maquiladora industry. As part of the NAFTA tariff schedule, the Mexican automotive industry followed a gradual tariff reduction for its imports by 6.5 percent at the beginning of the treaty, 25.3 percent in 1998, 74.7 percent in 2002, reaching 100 percent in 2004 (Carbajal \& Del Moral, 2014). Another requirement that was relaxed at the time was the condition of keeping a positive trade balance. Under NAFTA complete integration, the Mexican automotive industry specialized in the final production of small cars for the U.S. market, while opening the domestic market to imported final automobiles. The significance of the automotive sector affects a gradual increase of the nonmaquiladora horizontal IIT against the vertical as shown in Graph 3. This change in the trade pattern does not mean a reduction in VS, at least for the 1994-2006 period. Graph 4 that the vertical nature of the maquiladora trade flows has experienced a small reduction since 2003, which coincides with the period of gradual tariff reduction. Furthermore, the same graph shows that where prices of exports have been higher than prices of imports, the percentages of vertical IIT have been higher than 50 percent (with the exception of 1998, which is another year where there was a new set of tariff reductions for the automotive industry) and that reveals back-and-forth transactions.

Graph 3 shows the price of exports and the price of import indicators for the 1994-2014 period. While VS has been evident in the maquiladora industry (Graph 4), in the non-maquiladora industry (1994-2006 period), VS has been mixed. During the period where vertical IIT was a prominent part of the total IIT, the percentage of VS increased, reaching more than 80 percent in 2001. Likewise, when the participation of the vertical IIT declined, the percentages where prices of exports are higher than prices of imports also declined. Yet, as the calculation of IIT incorporates the maquiladora trade flows starting in 2007, the percentages for vertical specialization (back and forward transactions) started to rise again, which highlights that even though the maquiladora does not persist in the statistics, its effects were marked for the 2007-2014 period. This means that trade between Mexico and the U.S. is becoming more horizontal in nature, while retaining sectors where the vertical IIT is significant with back and forth transactions. The character of Mexican bilateral trade with the U.S. is heterogeneous in the manufacturing industry, which is consistent with heterogeneous and concentrated production.

Even though Canada has not been an established destination or origin of trade flows in Mexico, this country has become an expanding trade partner as a result of NAFTA, mainly through the trade of automotive industry products. Graphs 5 and 6 show the indexes for the non-maquiladora and maquiladora bilateral trades respectively.

Unlike previous graphs, the vertical nature of the bilateral IIT indexes for Mexico and Canada is evident regardless of the type of trade, maquiladora or non-maquiladora. Regarding the non-maquiladora trade flows (1994-2006), Graph 5 shows that trade is primarily one-way. The total IIT was 10 percent at the beginning of the treaty, reaching nearly 30 percent twenty years later. The IIT is vertical in nature until 2002 when gradual integration in the automotive industry was completed within NAFTA, evidenced by an increase in trade flows of products of different varieties (horizontal IIT) from that date. In Graph 5 , the difference between total IIT and vertical IIT is horizontal IIT. Even after 2006 when maquiladora trade flows were recorded as part of total trade, trade in goods of different varieties (horizontal IIT) continues. The significance of the 3841 sector, the automotive industry, which accounts for about 50 percent of the manufacturing trade between these two countries, explains this phenomenon. 


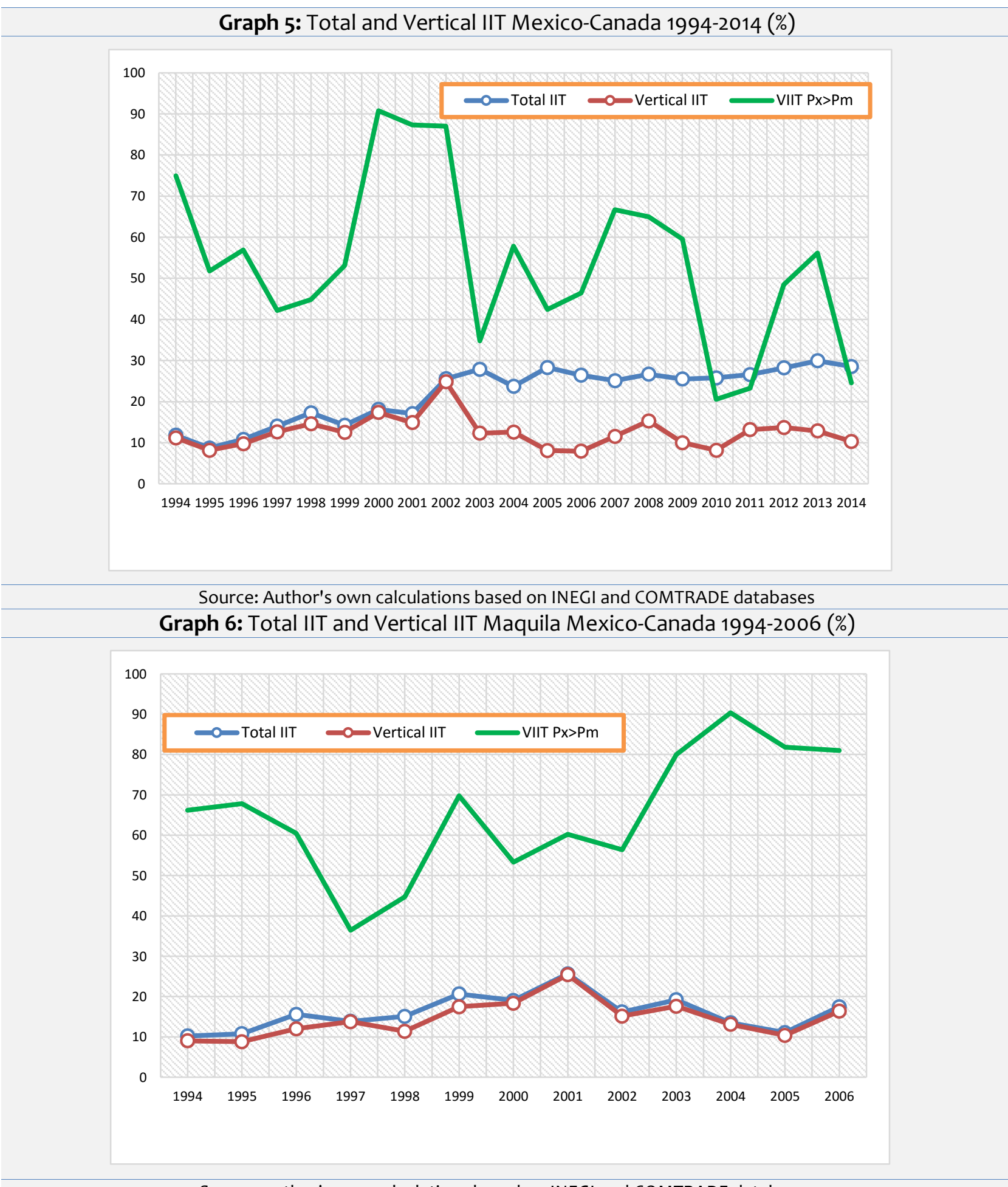

Source: author's own calculations based on INEGI and COMTRADE databases

Changes in the VS index are noticeable for some years, as shown in Graph 5. For instance, as IIT is mainly vertical until 2002, prices of exports are higher than prices of imports, indicating the condition of back and forth transactions in the bilateral trade. The same graph illustrates the increases. However, there is a big drop from 2002-2003, which coincides with the changes in the automotive industry NAFTA tariff schedule. In the case of Canada, the changes are affecting the trade of automotive engines, which changed from a vertical nature to be more horizontal. Another noticeable change was between 2009 and 2010, explained again by changes in the automotive industry, which shifted from being mostly vertical IIT to an increase of horizontal IIT.

Looking at the results for the maquiladora trade between these two countries, the trend is clear for the 
1994-2006 period: it is of a vertical nature and the back and forth trade can be seen in Graph 6 where percentages of prices of exports are higher in relation to prices of imports, which reached around 80 percent for the final years of the maquiladora program.

In sum, the VS that occurs in the trade between Mexico and Canada occurs mostly in the automotive industry sector, accounting for a significant proportion of the total manufacturing trade between these two countries. Any changes in the automotive sectors determines the final outcome of the total trade. However, the quantitative estimations show in this case the significance of VS.

\subsection{SUMMARY AND CONCLUSIONS}

In this article, we reviewed the theoretical and empirical literature of VS as the appropriate framework for analyzing trade flows of the Mexican manufacturing industry, which includes the maquiladora industry.

Technological development in the area of communications and services has enabled the dis-integration of production blocks across national boundaries where they can be produced at lower prices. Thus, less developed countries can compete in production in those blocks in which they are more efficient. While multinational firms have been the primary drivers of these changes, given the trade between headquarters and subsidiaries, independent companies are executing these actions with increasing frequency. Thus, researchers usually denote this process as vertical specialization of international production, even though the literature review included the different names used during these years.

These changes in the strategies away from only intra-firm trade have caused the more complicated quantification of trade flows. The literature review shows the challenges for proper quantification of this VS. First, for example, international statistics do not yet incorporate the growing number of intermediate goods traded, and secondly, an intermediate product can pass through several national borders, making registration more complicated.

Taking into consideration the significance of maquiladora trade flows in Mexican manufacturing trade, in this work we considered the Ando (2006) approximation of VS through the estimation of vertical IIT. In doing so, we were able to differentiate between maquiladora and non-maquiladora trade flows for the 1994-2006 period, while analyzing trade flows post-maquiladora until 2014. We confirmed different trade patterns for the non-maquiladora and maquiladora industries. While the latter is mainly vertical IIT in nature, the non-maquiladora went through a process of change with the 2002 NAFTA schedule changes the automotive industry. This change occurred before the end of the registration of maquiladora trade flows in 2002-2003 when the increase in horizontal flow trade became noticeable. Furthermore, in contrast to Ando's quality ladder hypothesis, the remaining vertical IIT was still considered back-and-forth transactions and not simply trade of different qualities of product.

These findings are more evident when analyzing bilateral trade flows. We chose to analyze NAFTA partners: Mexico-United States and Mexico-Canada. Since the United States is the main trade partner for Mexico, those results are similar to the analysis for the whole country. The analysis with Canada turned out to be a good example of how VS happens when one sector of the industry concentrates the trade flows. In this case, the trade flows in the automotive industry (sector 3841) accounted for around 50 percent of the total manufacturing trade between these two countries. The results for the maquiladora trade flows confirmed the vertical nature of this trade with back-and-forth transactions while the trade flows in the non-maquiladora industry changed with NAFTA to more horizontal in nature. Still, the vertical IIT flows are seen as back-and-forth transactions, not following the quality ladder hypothesis.

These results at the aggregate level show Mexico's position in the global value chain. This participation is not homogeneous in all manufacturing sectors, given the significant share of the automotive sector in total traded. This suggests the need for a more in-depth analysis of industrial sectors where Mexico could have advantages by integrating other sectors to a global value chain. In 2014 INEGI began to publish data 
on an industrial level with estimates of domestic content of exports dating back to 2003 (INEGI, 2014), though without differentiating between non-maquiladora and maquiladora. Thus, it is important to identify exported goods outside the automotive industry that show higher domestic value added and that potentially integrate to a global value chain.

\section{REFERENCES}

Amador, J., \& Cabral, S. (2009). Vertical Specialization across the world: A relative measure. North American Journal of Economics and Finance, 20(3), 267-280.

Ando, M. (2006). Fragmentation and vertical intra-industry trade in East Asia. North American Journal of Economics and Finance, 17(3), 257-281.

Arndt, S. W. (2001). Offshore sourcing and production sharing in preference areas. In S.W. Arndt \& H. Kierzkowski (Eds.), Fragmentation: New Production Pattern in the World Economy (pp. 77-87). Oxford, U.K.: Oxford UP.

Baldone, S., Sdogagi, F., \& Tajoli, L. (2001). Patterns and determinants of international fragmentation of production: Evidence from outward processing trade between the EU and Central Eastern European countries. Review of World Economics, 137(1), 80-104.

Baldwin, R., \& Robert-Nicoud, F. (2014). Trade-in-goods and trade-in-tasks: An integrating framework. Journal of International Economics, 92(1), 51-62.

Bastos, P., \& Silva, J. (2010). Identifying vertically differentiated products. Economics Letters, 106(1), 3234.

Borga, M., \& Zeile, W. J. (2004). International fragmentation of production and the intra-firm trade of U.S. multinational companies (BEA Working Paper 2004-02).

Breda, E., Cappariello, R., \& Zizza, R. (2008). Vertical Specialization in Europe: Evidence from the import content of exports (Bank of Italy Temi di Dicussione Working Paper No. 682).

Campa, J., \& Goldberg, L. S. (1997). The evolving external orientation of manufacturing: A profile of four countries. FRBNY Economic Policy Review, 3, 53-80.

Carbajal, Y., \& Del Moral, L. (2014). El desempeño del sector automotriz en México en la era TLCAN. Un análisis a 20 años. Paradigma Económico 6(1), 95-126.

Castillo, J. C., \& de Vries, G. J. (2013, July). The domestic content of Mexico's maquiladora exports: 19882006. Paper presented at The Wealth of Nations in a Globalizing World, Groningen, The Netherlands.

Clark, D. (2010a). Intra-industry specialization in United States-Mexico Trade. Global Economy Journal, $10(2), 1-16$.

Clark, D. (2010b). Vertical specialization with developed and developing countries. Journal of Developing Areas, 43(2), 327-339.

Clark, D., Sawyer, W. C., \& Sprinkle, R. L. (1993). Determinants of offshore assembly in developing and developed countries. Social Science Quarterly, 74(4), 771-782.

Daudin, G., Rifflart, C., \& Schweisguth, D. (2011). Who produces for whom in the world economy? Canadian Journal of Economics, 44(4), 1403-1437.

Dean, J., Fung, K. C., \& Wang, Z. (2011). Measuring vertical specialization: The case of China. Review of International Economics, 19(4), 609-625.

Deardorff, A. V. (2001). Fragmentation in simple trade models. North American Journal of Economics and Finance, 12(2), 121-137.

De la Cruz, J., Koopman, R. B., Wang, Z., \& Wei. S.-J. (2013). Foreign and domestic content in Mexico's manufacturing exports. In A. Mattoo, Z. Wang, and S.-J. Wei (Eds.), Trade in Value Added: Developing New Measures of Cross-Border Trade (pp. 135-160). Centre for Economic Policy Research: World Bank.

Dixit, A. K., \& Stiglitz, J. (1977). Monopolistic competition and optimum product diversity. American Economic Review, 67(3), 297-308.

Ekanayake, E. M., Veeramacheneni, B., \& Moslares, C. (2009). Vertical and horizontal intra-industry trade between the U.S. and NAFTA partners. Revista de Análisis Económico, 24(1), 21-42.

Ethier, W. J. (1982). National and international returns to scale in the modern theory of international trade. American Economic Review, 72(3), 389-405.

Feenstra, R. C. (1998). Integration of trade and disintegration of production in the global economy. Journal 
of Economic Perspectives, 12(4), 31-50.

Feenstra, R. C., \& Hanson, G. H. (2003). Global production sharing and rising inequality: A survey of trade and wages. In E. K. Choi \& J. Harrigan (Eds.), Handbook of International Trade (pp. 146-185). Madsen, Mass: Blackwell Publishing Ltd.

Feenstra, R., C., \& Hanson, G. H. (1997). Foreign direct investment and relative wages: Evidence from Mexico's maquiladoras. Journal of International Economics, 42(3-4), 371-393.

Feenstra, R. C., \& Hanson, G. H. (1996a). Foreign investment, outsourcing and relative wages. In R. Feenstra, G. Grossman, \& Irvin, D. (Eds.), Political Economy of Trade Policy: Essays in Honor of Jagdish Bhagawati (pp. 89-127). Cambridge, Mass: MIT Press.

Feenstra, R. C., \& Hanson, G. H. (1996b). Globalization, outsourcing and wage inequality. American Economic Review, 86(2), 240-245.

Fontagné, L., \& Freudenberg, M. (1997). Intra-Industry Trade: Methodological Issues Reconsidered. (CEPII Working Paper 97-01).

Greenaway, D., \& Milner, C. (1984). A cross section analysis of intra-industry trade in the U.K. European Economic Review, 25(3), 319-344.

Grossman, G., \& Rossi-Hansberg, E. (2006). The rise of offshoring: It's not wine for cloth anymore. In The New Economic Geography: Effects and Policy Implications: A Symposium (pp. 59-106). Federal Reserve Bank of Kansas City.

Grunwald, J., \& Flam, K. (1985). The Global Factory. Foreign Assembly in International Trade. Washington, D.C.: Brookings Institution.

Hanson, G. H., Mataloni, R. J., \& Slaughter, M. J. (2005). Vertical production networks in multinational firms. Review of Economics and Statistics, 87(4), 664-678.

Hanson, G. H. (1996). Economic integration, intra-industry trade, and frontier regions. European Economic Review, 40(3-5), 941-949.

Helpman, E., \& Krugman, P. (1985). Market structure and foreign trade: Increasing returns, imperfect competition, and the international economy. Economic Journal, 96(381), 243-245.

Hummels, D., Ishii, J., \& Yi, K-M. (2001). The nature and growth of vertical specialization in world trade. Journal of International Economics, 54(1), 75-96.

Hummels, D., Rapoport, D., \& Yi, K-M. (1998). Vertical specialization and the changing nature of world trade. Federal Reserve Bank of New York Economic Policy Review, 4(2), 79-99.

Inomata, S. (2008). A new measurement for international fragmentation of the production process: An international Input-Output approach (Institute of Developing Economies Discussion Paper 175).

Instituto Nacional de Estadística, Geografía e Informática. (2014). Valor agregado de exportación de la manufactura global. Sistema Nacional de Cuentas Nacionales. Metodología. México DF.

Jiang X., \& Milberg, W. (2012). Vertical Specialization and industrial upgrading: A preliminary note (University of Manchester Capturing the Gains Working Paper No. 10).

Jones, R. W., \& Kierzkowski, H. (2005). International fragmentation and the new economic geography. North American Journal of Economics and Finance, 16(1), 1-10.

Jones, R. W., \& Kierzkowski, H. (2001). A framework for fragmentation. In S.W. Arndt \& H. Kierzkowski (Eds.), Fragmentation: New Production Patterns in the World Economy (pp. 17-33), Oxford, U.K.: Oxford UP.

Jones, R. W., \& Kierzkowski, H. (1990). The role of services in production and international trade: A theoretical framework. In R.W. Jones \& A. Krueger (Eds.), The Political Economy of International Trade (pp. 31-48). Oxford, U.K.: Basil Blackwell.

Kierzkowski, H. (2011). A new global auto industry? China and World Economy, 19(1), 63-89.

Kleinert, J. (2003). Growing trade in intermediate goods: Outsourcing, global sourcing or increasing importance of MNE Networks? Review of International Economics, 11(3), 464-482.

Koopman, R., Wang, Z., \& Wei, S.-J. (2014). Tracing value-added and double counting in gross exports. American Economic Review, 104(2), 459-94.

Koopman, R., Wang, Z., \& Wei, S.-J. (2012). Estimating domestic content in exports when processing trade is pervasive. Journal of Development Economics, 99(1), 178-189.

Krugman, P. (2008, Spring). Trade and wages, reconsidered. Brookings Papers on Economic Activity, 103154.

Lopez, J. L., \& Holmes, P. (2011). The nature and evolution of vertical specialisation: What is the role of 
preferential trade agreements? (Swiss National Centre of Competence in Research Working Paper 2011/41).

Lüthje, T. (2003). Intra-industry trade in intermediate goods and final goods in general equilibrium setting. Open Economies Review, 14(2), 191-209.

Meng, B., Yamano, N., \& Webb, C. (2010). Vertical Specialization indicator based on supply- driven inputoutput model (Institute of Developing Economies Discussion Paper No. 270.)

Nordas, H. (2008). Vertical Specialization and its determinants. Journal of Development Studies, 44(7), 1037-1055.

Pittiglio, R. (2014). An essay on intra-industry trade in intermediate goods. Modern Economy, 5(5), 468488.

OECD. (2009). Vertical Specialization and global value chains (International Trade in Goods and Trade in Services Statistics Working Paper STD/WPTGS 16).

Ricotta, F. (2009). Trade in intermediate goods in Italian manufacturing industries (Universita della Calabria Dipartamento di Economia e Statistica Working Paper 15).

Shelburne, R. C. (2004). Trade and inequality: The role of vertical specialization and outsourcing. Global Economy Journal, 4(2), 1-32.

Türkcan, K. (2011). Vertical intra-industry trade and product fragmentation in the auto-parts industry. Journal of Industry, Competition and Trade, 11(2), 149-186.

Türkcan, K. (2005). Determinants of intra-industry trade in final goods and intermediate goods between Turkey and selected OECD countries. Istanbul University Econometrics and Statistics e-Journal, 1(1), 2140.

Valderrama, A. L., \& Neme, O. (2011). Los determinantes del comercio intraindustrial, horizontal y vertical, en las industrias manufactureras de México. Estudios Económicos, 26(1), 35-58.

WTO-IDE-JETRO. (2011). Trade patterns and global value chains in East Asia: From trade in goods to trade in tasks. Geneva, Switzerland: World Trade Organization.

Yang, C., Dietzenbacher, E., Pei, J., \& Chen, X. (2015). Processing trade bias in measuring vertical specialization. Economic Systems Research, 27(1), 60-76.

Yeats, A. (2001). Just how big is global production sharing? In S.W. Arndt \& H. Kierzkowski (Eds.), Fragmentation: New Production Patterns in the World Economy (pp. 108-143). Oxford, U.K.: Oxford UP. 